\title{
ブロックゲージの密着トルクの特性 ${ }^{*}$
}

\section{一ブロックゲージの密着力に関する研究（第 $\mathbf{5}$ 報）——}

\author{
津村喜代治** 藤 井 康 治***
}

Characteristics of Wringing Torque of Block Gauges

- Study on Wringing Force of Block Gauges (Report 5) -

Kiyoji Tsumura, Yasuharu FujII

The basic characteristics of wringing torque were analyzed in the previous report. This time we have experimentally confirmed the effects on wringing torque of surface roughness, flatness, etc. of the wringing surfaces of block gauges, and studied on whether or not industrial use can be made of the newly defined wringing torque. The results are summarized as follows :

1. Deducing from the measurements of wringing torque, the thickness of oil film is about equal to $1 / 2$ of the sum of the surface roughnesses of the block gauges wrung together.

2. The thickness of oil film in the best wringing conditions is assumed to be on the order of $0.02 \mu$.

3. It believably is possible to evaluate wringing torque by means of wringing force.

\section{1. まえがき}

第 4 報1に尔いて密着トルクの基礎特性について解析 した結果, 密着トルクの生ずる原因は密着面間に介在す る油の表面張力と粘性によるものであることを明らかに した.

この報ではブロックゲージの密着面の表面あらさ，平 面度などの密着トルクへ及ぼす影響を実験により確認 し，またこの新しく定義した密着トルクが工業上採用で きるか否かを検討してみたい.

実験装置および実験方法㳊第 4 報において述べたもの と同様である.

\section{2. ブロックゲージの特性と密着トルクとの関係}

\section{1 密着面面積と密着トルクとの関係}

密着面に平行な方向の断面について, 正方形の断面形 状をもつ Hoke Gage, 円形断面形状をもつ Cary Slip Gauge を除き, 断面形状が長形のものについて BS, DIN などの諸外国規格および Johansson, Webber などの諸 メ一カ規格について断面寸法を調查した.この結果断面 寸法㵊大 $38.3 \times 13.5\left(\mathrm{~mm}^{2}\right)$, 最小 $20 \times 9\left(\mathrm{~mm}^{2}\right)$ の範 囲であった。

この断面寸法の範囲内において, 断面寸法と密着トル

*原稿受付 昭和 45 年 9 月 25 日. 昭和 45 年度精機学会春季大 会学術講演会 (昭和45年 4 月 3 日) にて発表.

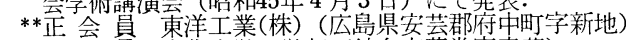

***正 会 員 東北大学工学部 (仙台市荒巻字青葉)
クとの関係の実験結果を図 1 に示してある。 また前報1) より各種断面寸法の密着トルク $T$ を求める式を導びくと 断面寸法 $35 \mathrm{~mm} \times 9 \mathrm{~mm}$ の場合 $T=0.36 \alpha \eta \frac{N}{h} \times 10^{-6}+2.8 \mu\left(\frac{2 \sigma \cos \theta}{h} \times 10^{-6}+p\right)$ 断面寸法 $30 \mathrm{~mm} \times 9 \mathrm{~mm}$ の場合 $T=0.23 \alpha \eta \frac{N}{h} \times 10^{-6}+2.1 \mu\left(\frac{2 \sigma \cos \theta}{h} \times 10^{-6}+p\right)$ 断面寸法 $25 \mathrm{~mm} \times 9 \mathrm{~mm}$ の場合 $(1)$ $T=0.14 \alpha \eta \frac{N}{h} \times 10^{-6}+1.4 \mu\left(\frac{2 \sigma \cos \theta}{h} \times 10^{-6}+p\right)$ 断面寸法 $20 \mathrm{~mm} \times 9 \mathrm{~mm}$ の場合 $T=0.08 \alpha \eta \frac{N}{h} \times 10^{-6}+0.9 \mu\left(\frac{2 \sigma \cos \theta}{h} \times 10^{-6}+p\right)$

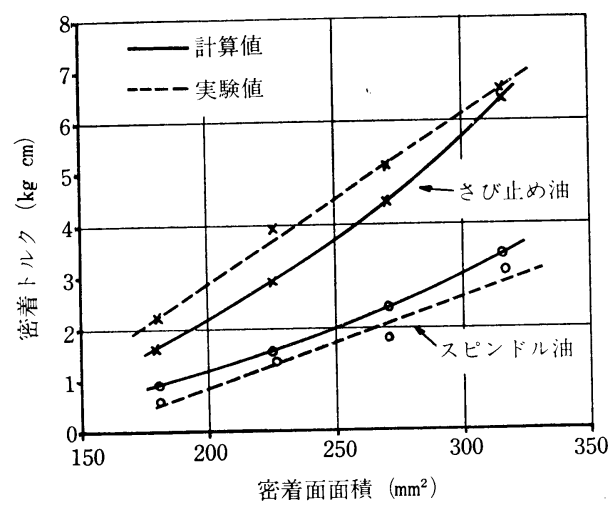

図 1 密着面面積と密着トルクとの関係 
となる。

ここに

$\alpha$ は粘性係数の補正係数

クは粘性係数

(poise)

$N$ は回転速度

$h$ は油膜の厚さ

(rpm)

(cm)

$\mu$ は付着係数

$\sigma$ は表面張力

(dyn/cm)

$\theta$ 注接触角

かはブロックゲージの自重を含む単位

$$
\text { 面積あたりの押付圧力 }
$$

$\left(\mathrm{kg} / \mathrm{cm}^{2}\right)$

である

この式に実験の諸条件を代入して求めた値を計算値と して図 1 に示してある.計算值と実験値とはほぼ一致す ることが認められる。したがって断面寸法の異なるブロ ックゲージの密着トルクは式(1)によって評価することが できる・

\section{2 密着面の表面あらさと密着トルクとの関係}

密着面の表面あらさと密着力との関係は重要な問題の 一つである.ここでは表面あらさと密着トルクとの関係 を実験により求めた。 その結果を図 2 (a)〜 (c) に示し てある。表面あらさは触針式あらさ測定機（触針半径 $2.5 \mu$, 測定力 $0.1 \mathrm{~g}$ ) により測定し最大高さを求めた. この図の横軸は密着したブロックゲージの最大高さの和 の $1 / 2$ をとって表面あらさとして表示した。この図にお いて表面あらさの値が大きくなると密着トルクは急激に 低下することがわかる。

また横軸の值を油膜の厚さと仮仚して部算して求めた 密着トルクの值を計算値として戍 2 に示してある。この 計算值と実験值とはほぼ一致している。この結果から表 面あらさはブロックゲージを密着した場合の油膜の厚さ と関係があると考えられ, 油膜の厚さはブロックゲージ の表面あらさと同程度であるという報告2) の妥当性を裏

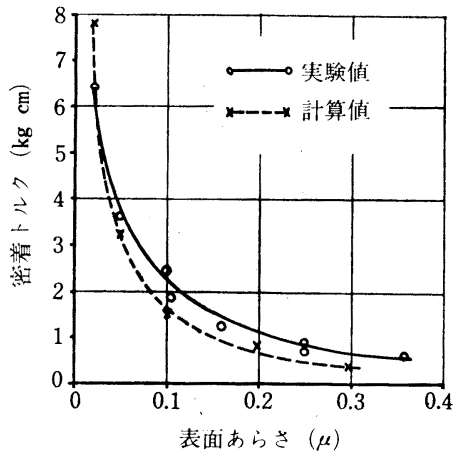

図 2 （a）表面あらさと密着トルク との関係（さび止め油）

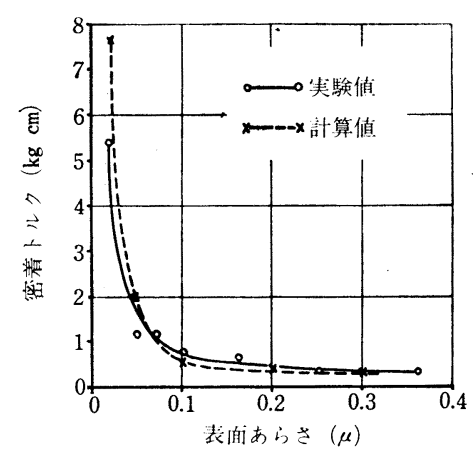

図 2 (b) 表面あらさと密着トルク との関係（ひまし油）

\section{3 密着面の平面度と密着トルクとの関係}

密着面の平面度は密着力に影響することは当然考えら れる現象である．この平面度と密着トルクとの関係の実 験結果を図 3 に示してある.

平面度は光波干涉計で測定し, 平面度誤差の形状は密 着面全面にわたって円弧状である.

密着面に対して平行な断面の長手寸法方向における平 面度が密着トルクへ及ぼす影響を実験する場合には，短 手方向の平面度は $0.005 \mu$ 以下とした. 短手の断面寸法 方向における平面度の場合には, 長手方向の平面度は $0.01 \mu$ 以下とした.

図 3 の横軸の値はつぎのように求めたものである.す なわち密着面の平面度の異なった組合わせを模型的に図 4 に示してある.この図において（a)，(b) に示す中高 および中低状の平面状態同志を組合わせたときは，上下 ブロックゲージの平面度の和を密着面平面度とし，(c) の条件の中高状と中低状との平面の組合わせの場合に

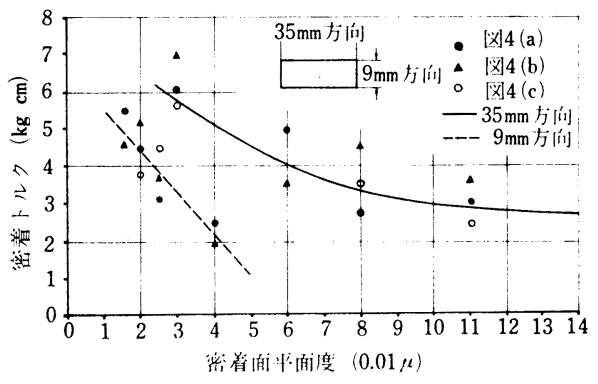

図 3 密着面平面度と密着トルクとの関係

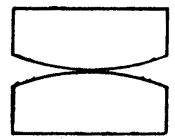

(a)

图 4 密着面平面度の組合わせ条件

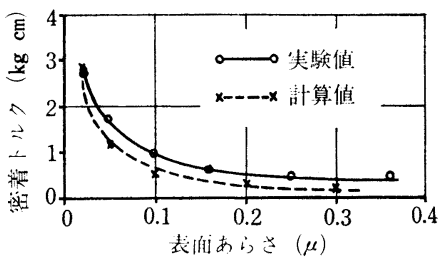

図 2（c）表面あらさと密着トルク との関係(スピンドル油)

精密機械 38 巻 2 号 


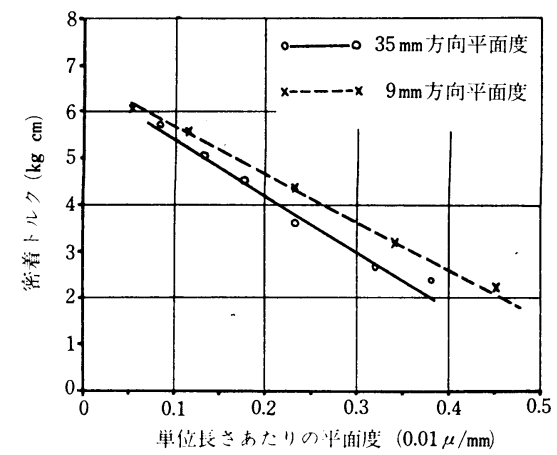

図 5 単位長さあたりの平面度と密着トルクとの関係

には, おのおのの平面度の差の絶対値を密着面平面度と して横軸の值としてある.

図 3 から見ると短手方向の平面度が密着トルクへ及ぼ す影響は，長手方向の影響に比較して大である.しかし 密着面平面度を単位長さあたりの平面度に換算したもの を図 5 に示してある。この図から見ると長手, 短手各方 向の単位長さあたりの平面度と密着トルクとの関係はほ ぼ同等であることがわかる。

\section{3. 油膜の厚さと密着トルクとの関係}

油膜の厚さと密着力との関係は重要な問題の一つであ るが，これらの関係を実験的に調べた。

油膜の厚さと密着トルクとの関係の実験結果を図6(a) 〜 (e) に示してある.この図においていろいろの油を使 用したときの最良条件における密着トルクを求めると表 1 のようになる。この表から密着合成長さに誤差を含ま ないような条件における密着トルクをみいだすことがで きる。

油膜の厚さはつぎのように求めた。実験に使用するブ ロックゲージを光波干涉計により絶対寸法を測定した. トルク試験機により 2 個のブロックゲージを密着させ て, 比較測定器により密着合成長を求めた。 この場合 2 個のブロックゲージの絶対寸法の和と密着合成長の比較 測定值とが一致した場合には油膜の厚さは $0.02 \mu$ とし， 両者に差があった場合には，この差に $0.02 \mu$ を加えた 値を油膜の厚さとした ${ }^{3)}$.

表 1 密着最良条件の時の密着トルク

\begin{tabular}{|c|c|}
\hline 油 の 種 類 & 密着トルク $(\mathrm{kgcm})$ \\
\hline さび 止 め 油 & 6.4 \\
\hline ひ む し 油 & 6.0 \\
\hline グ リ セ リ ン & 6.0 \\
\hline スピンドル油 & 2.5 \\
\hline エチレングリコール & 4.1 \\
\hline
\end{tabular}

つぎにトルク試験機により密着トルクを求めた後, 再 び比較測定機により密着合成長を測定した。密着トルク の測定前後の密着合成長が, $0.02 \mu$ をこえる差のあった 場合には，密着トルクの測定值は採用しなかった。

式(1)の断面寸法 $35 \mathrm{~mm} \times 9 \mathrm{~mm}$ の場合の式より密着卜 ルクを測定した諸条件を代入して求めた計算值と実験值 とはほぼ一致していることが認められた。この結果から 油膜の厚さ滵着の最良条件において $0.02 \mu$ と仮定し たこと $\left.{ }^{3}\right)$ が妥当であったことが確認されたことになる。

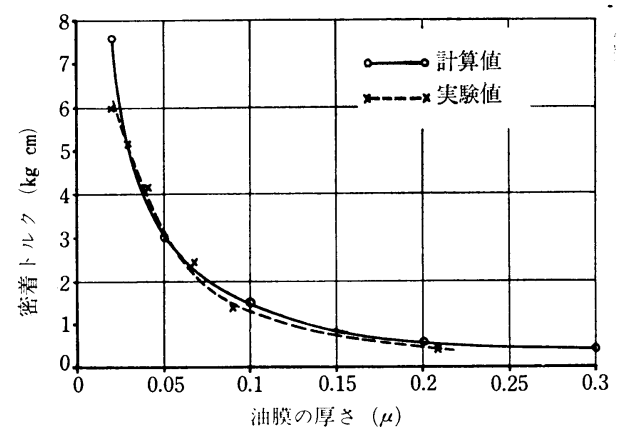

図 6 （a）油膜の厚さと密着トルクとの関係(グリセリン)

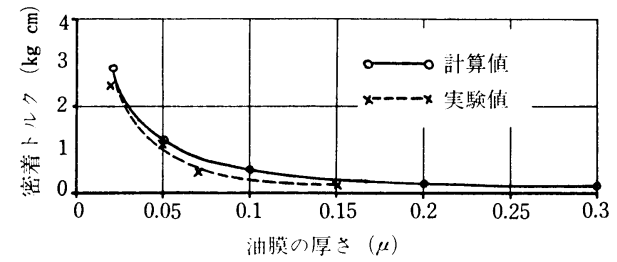

図 6 (b) 油膜の厚さと密着トルクとの関係(スピンドル油)

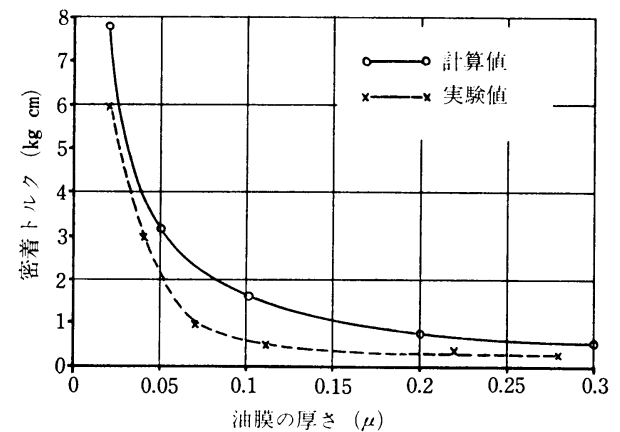

図 6（c）油膜の厚さと密着トルクとの関係(ひまし油)

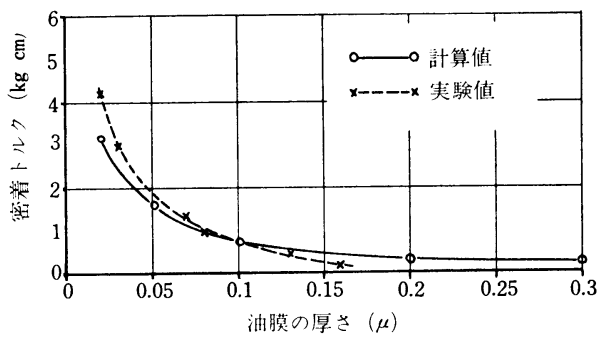

図 6（d） 油膜の厚さと密着トルクとの関係 (エチレングリコール) 


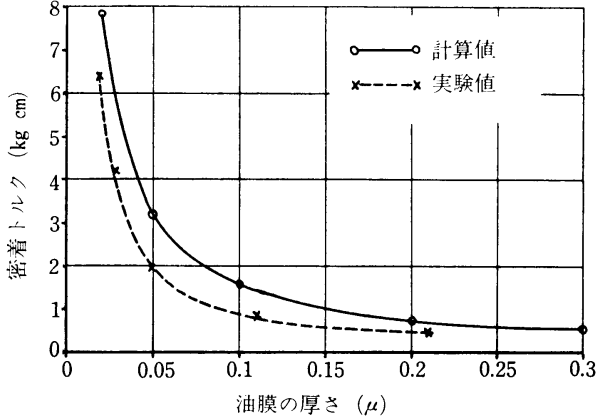

図 6（e）油膜の厚さと密着トルクとの関係(さび止め油)

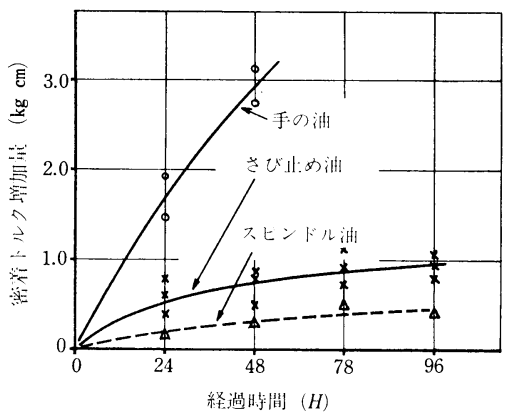

図 7 密着後の経過時間と密着トルクとの関係

\section{4. 密着後の経過時間と密着トルクとの関係}

ブロックゲージを密着してそのままの状態で放置する と, 密着後時間の経過にともない密着力はしだいに上昇 するといわれている．この原因について Rolt ら"は研 究の結果密着面間に介在する油の抬散によるものとして いる.

密着後の経過時間と密着トルクとの関係についての実 験結果を図 7 に示してある。密着作業は密着トルク試験 機1)で行ない, 最初の密着トルクはさび止め油 $6 \mathrm{~kg} \mathrm{~cm}$, スピンドル油 $3 \mathrm{~kg} \mathrm{~cm}$ を目標とした。密着作業終了後は この試験機よりブロックゲージを取り出して, ブロック ゲージの自重のみの荷重がかかるように放置した.

密着トルクは密着トルク試験機を使用して測定し, 前 報において述べた図 1 (b) の状態から，下のブロックゲ ージを回転させた時の最大值である。また密着トルクを 測定した後，上下ブロックゲージは密着トルク試験機に より，図1(a) の状態に先に述べた密着トルクを目標值 として復元した。つぎの密着後の経過時間まで放置し た。

この感から明らかなようにさび止め油，スピンドル油 を使用した場合の密着トルクは 24 時間経過するまでの 上昇度合は 24 時間以後の变化の度合より大であるが, 96 時間経過してトルクの増加量は $1 \mathrm{~kg} \mathrm{~cm}$ 程度である.

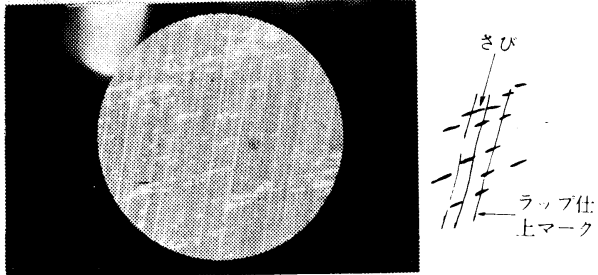

図 8 密着面に発生したさび $(\times 23.5)$

これに対して油に手の油を使用した場合の密着トルク注 前 2 者と比較して上昇する度合は大であった。しかし 48 時間経過したものの密着面を観測すると, 図 8 に示 すように，さびの発生していることがわかったここの場 合密着トルクの上昇原因はブロックゲージ同志のさび付 によるものと考えられる. 他方さび止め油, スピンドル 油を使用して密着した場合には，96 時間経過しても密 着面にはさびの発生は観測されなかった。

\section{5. 密着トルクの工業的応用}

密着トルクの特性を解析し, 密着トルクにより密着力 を評価することができることが明らかになった。

前報までに報告した付着力, 接線抵抗力, 引張力, 密 着トルクおよび折離力 ${ }^{5}$ について, 測定精度, 寸法精度 との関係などを比較して表 2 に示してある. この表から 見て密着トルクにより密着力を保証する方法を採用して みた。

ブロックゲージの生産面において密着トルクを管理し た結果について, 密着トルクの管理図の代表的なものを 図9(a)，(b)，(c)に示してある.

この管理図の作成条件はつぎのとおりである.

1） 24 個を 1 ロットとして寸法測定を行なった結果, このロット中の寸法偏差が最良のものと最悪なもの 2 組 をを抜き取り，密着トルクを測定する。

2）密着に使用した油は密着作業の準備を容易にする ため，さび止め油と同系統のさび止めグリースを採用す る.

図 9 (a) において A，B，C点など密着トルクが低下し

表 2 各種測定法の比較

\begin{tabular}{|c|c|c|c|c|}
\hline & 測定精度 & 測定難易度 & $\begin{array}{l}\text { 寸法精度 } \\
\text { との関係 }\end{array}$ & 測定可能寸法 \\
\hline 付 着 力 & - & 不可能 & 有 & - \\
\hline 接線抵抗力 & 高 & 容易 & 有 & 約 $5 \mathrm{~mm}$ 以上 \\
\hline 密着トルク & 高 & & 有 & 約 $1 \mathrm{~mm}$ 以上 \\
\hline 引 張 力 & 低 & 困 & 有 & 約 $10 \mathrm{~mm}$ 以上 \\
\hline 折 離 力 & 低 & 困 & 無 & 約 $20 \mathrm{~mm}$ 以上 \\
\hline
\end{tabular}




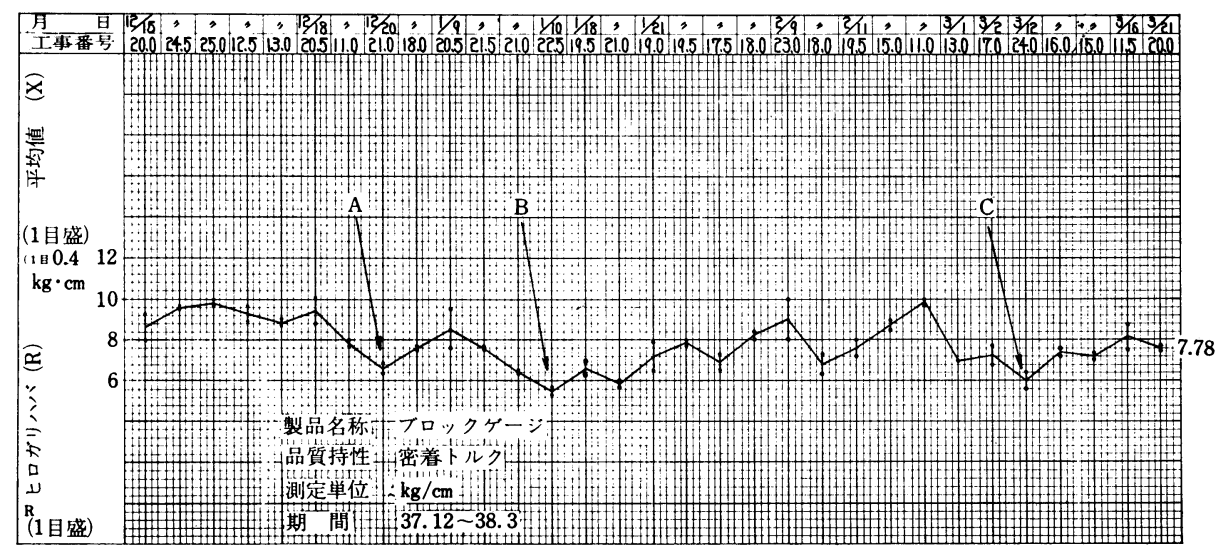

図 9（a）密着トルクの管理図（昭和 38 年）

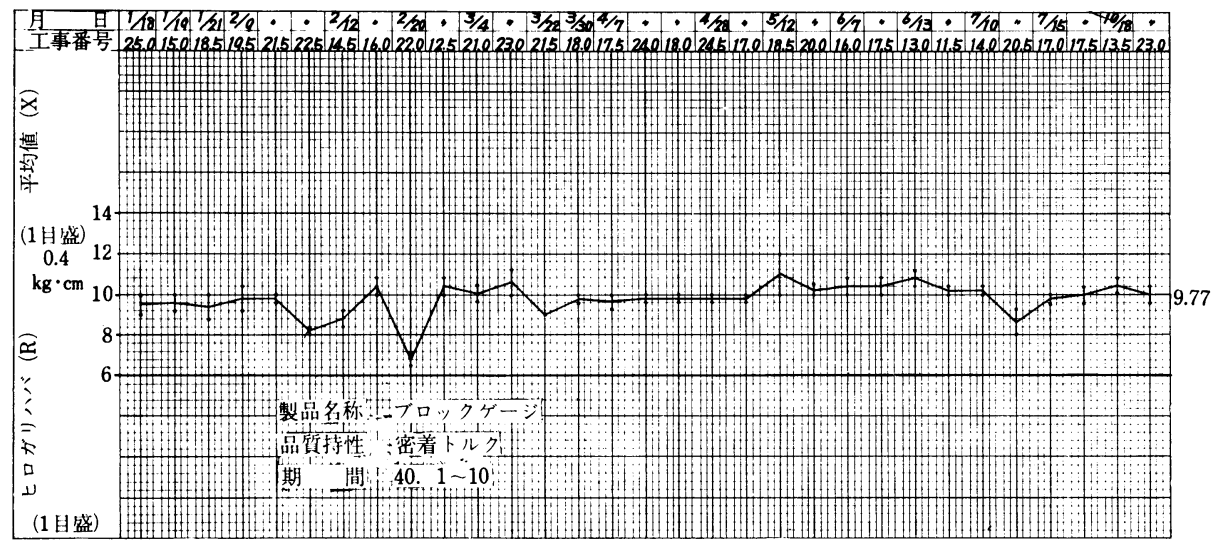

図 9（b） 密着トルクの管理図（昭和 39 年)

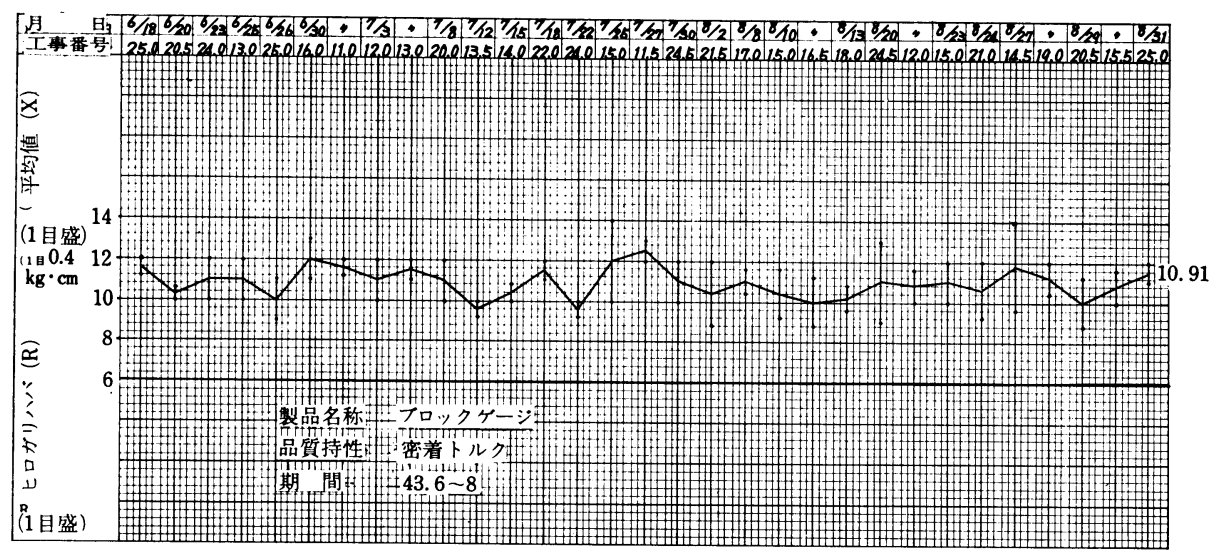

図 9（c） 密着トルクの管理図（昭和 43 年）

ている点がある.この低下の原因について調査した結 果, ラップ仕上用定盤の平面度が悪化したことに起因す ることがわかった。このためラップ仕上定盤の平面度を
修正する周期を管理図から設定するという対策をたて た。

密着トルクを管理して以来各年度における密着トルク 


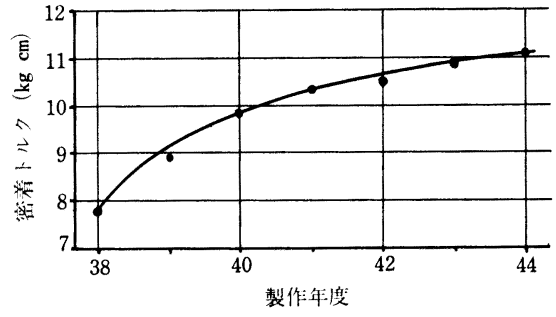

図 10 密着トルクの推移

の平均值を示すと図 10 のようにな。この図から見て 密着トルクは次第に上昇していることがわかり, 密着卜 ルクにより密着性を管理したことによる効果が認められ る.

\section{6. むすび}

密着トルクについて検討した結果つぎのことが考えら れる。

1. 密着トルクを測定した結果から推測して, 密着面 の表面あらさは油膜の厚さに関係してくる. 密着したブ ロックゲージの表面あらさの和の $1 / 2$ が油膜の厚さにほ ぼ等しくなる.

2. 最良の密着条件のときの油膜の厚さは $0.02 \mu$ 程
度であるとみなしてよいことが推測される。

3. 密着後の経過時間に比例して密着トルクは上昇す るが，その上昇は $1 \mathrm{~kg} \mathrm{~cm}$ 程度である.

4. 密着トルクで密着力を評価することは可能であ る。また計測が他の力と比較して容易であり，工業的に ブロックゲージの密着力を評価する方法として採用でき ると思われる。

おわりにこの一連の研究にご指導賜わった東北大学工 学部佐藤健児, 营場孝雄, 松井正己教授に深く感謝する ものである. またこの研究を進めるにあたり，ご教示と ご援助を賜わった東洋工業株式会社副社長村尾時之助 氏，専務取締役竹林清三氏，品質管理部長角田馨氏，技 術顧問田中重芳氏に厚く謝意を表するものである.

この研究報告は東北大学審査学位論文(博士)である.

\section{参 考 文 献}

1）津村, 藤井: ブロックゲージの密着トルクの解析, 精密機 械, 37, 12 (1971) 849.

2) 津上：ブロックゲージ，日刊工業新聞社 (1962) 37.

3）津村, 藤井: ブロックゲージの接線抵抗力について, 精密 機械, 37, 10 (1971) 695 .

4) F.H. Rolt, H. Barrell: Gauges and Fine Measurements, 1 (1929) 156. The Macmillan Company, New York.

5）津村：ブロックゲージの密着に関する研究 (第 2 報), 精 機学会東北地方講演会前刷, (1967-3). 